\title{
Identifying Political Risk Management Strategies in International Construction Projects
}

\author{
Tengyuan Chang $\mathbb{D}^{1},{ }^{1}$ Bon-Gang Hwang, ${ }^{2}$ Xiaopeng Deng $\mathbb{D}^{1},{ }^{1}$ and Xianbo Zhao $\mathbb{D}^{3}$ \\ ${ }^{1}$ School of Civil Engineering, Southeast University, Si Pai Lou, Nanjing 210096, China \\ ${ }^{2}$ Department of Building, National University of Singapore, 4 Architecture Drive, Singapore 117566 \\ ${ }^{3}$ School of Engineering and Technology, Central Queensland University, 400 Kent Street, Sydney, NSW 2000, Australia \\ Correspondence should be addressed to Xiaopeng Deng; dxp@seu.edu.cn
}

Received 19 April 2018; Accepted 20 May 2018; Published 25 June 2018

Academic Editor: Eric Lui

Copyright ( $) 2018$ Tengyuan Chang et al. This is an open access article distributed under the Creative Commons Attribution License, which permits unrestricted use, distribution, and reproduction in any medium, provided the original work is properly cited.

\begin{abstract}
International construction projects are plagued with political risk, and international construction enterprises (ICEs) must manage this risk to survive. However, little attention has been devoted to political risk management strategies in international construction projects. To fill this research gap, a total of 27 possible strategies were identified through a comprehensive literature review and validated by a pilot survey with 10 international experts. Appraisals of these 27 strategies by relevant professionals were collected using questionnaires, 155 of which were returned. Exploratory factor analysis was conducted to explore the interrelationships among these 27 strategies. The results show that all of the 27 strategies are important for political risk management in international construction projects. Moreover, these 27 strategies were clustered into six components, namely, (1) making correct decisions, (2) conducting favorable negotiations, (3) completing full preparations, (4) shaping a good environment, (5) reducing unnecessary mistakes, and (6) obtaining a reasonable response. The 6 components can be regarded as 6 typical management techniques that contribute to political risk management in the preproject phase, project implementation phase, and postevent phases. The findings may help practitioners gain an in-depth understanding of political risk management strategies in international construction projects and provide a useful reference for ICEs to manage political risks when venturing outside their home countries.
\end{abstract}

\section{Introduction}

With the rapid development of economic globalization, the global construction market has thrived in the past decade [1]. Moreover, the large market for construction in Asia, Africa, and Latin America will create widespread prosperity and opportunities for international construction enterprises (ICEs). By taking advantage of these opportunities, increasing numbers of international contractors will expand into the international construction market [2].

However, opportunities are always accompanied by risks, and ICEs will be exposed to new risks when venturing outside their home countries $[3,4]$. ICEs have witnessed a dramatic increase in political risks around the world, such as the credit crises in Greece, Venezuela, and Congo; the wars in southern Sudan, Syria, Afghanistan, and Libya; the terrorist attacks in Europe, the Middle East, Central Asia, and South Asia; and the coups in Niger, Thailand, and Honduras $[2,4,5]$. These risks had a very large negative impact on the global market and resulted in great losses for ICEs.

Given the increasingly complex business environment, political risks should not be ignored by ICEs when they approach global markets $[2,6,7]$. Political risk in international construction projects refers to uncertainty related to political events (e.g., political violence, regime changes, coups, revolutions, breaches of contract, terrorist attacks, and wars) and to arbitrary or discriminatory actions (e.g., expropriation, unfair compensation, foreign exchange restrictions, unlawful interference, capital restrictions, corruption, and labor restrictions) by host governments or political groups that may have negative impacts on ICEs [6]. Compared with the nonsystematic risks (e.g., technical risk, quality risk, procurement risk, and financial risk) of construction projects, political risk is 
more complex, unpredictable, and devastating and is usually outside the scope of normal project activities [2].

Much of the extant literature has focused on political risks in international general business $[8,9]$ but has paid less attention to political risks in international construction projects. In most cases, political risk management is practiced only as a part of risk management at the project level in construction projects. However, project-level political risks can also affect enterprises' objectives (e.g., financial, reputation, stability, survival, development, and strategic decisions) [10]. Implementation of political risk management only at the project level has some drawbacks: (1) lack of a comprehensive understanding of political risks; (2) overemphasis on short-term project goals and less consideration of corporate strategic objectives; (3) constraints because of limited resources or inappropriate resource allocation among projects; and (4) lack of accumulation and sharing of risk management experience. Therefore, risk management only at the project level no longer seems to be sufficient to help ICEs to address political risks in the global market [11].

Hence, political risk management in international construction projects should be conducted jointly at both the project and firm levels by considering the various types of risk and linking risk management strategies to the enterprise's objectives. Successful political risk management should be based on sufficient resources and information as important components of the decision-making process are continually improved and enhanced [12]. At the firm level, political risks can be treated as part of the entire risk portfolio of an enterprise and can be addressed across multiple business areas $[13,14]$. Implementation of political risk management at the firm level can lead to better coordination and consolidation of the resources and goals of the enterprise, which is more conducive to the long-term stability and development of ICEs [15].

This study focuses on the political risk inherent in international construction projects and aims at identifying the strategies available for ICEs to manage political risk. The specific objectives of this study are to (1) identify possible risk management strategies that can address political risks in international construction projects, (2) evaluate the importance of the strategies, and (3) explore the interrelationships among those strategies and their practical applications in international construction projects.

Because less attention has been devoted to political risk management in international construction projects, this paper can enrich the understanding of risk management in the field of international construction. Furthermore, this study may help practitioners clearly understand political risk management strategies in international construction projects and provide guidance for ICEs regarding how to address political risk when venturing outside their home countries.

\section{Literature Review}

Political risk management has been a popular topic in the field of international business (e.g., foreign direct investment, trade in goods, and international joint ventures). Several strategies have been proposed to address political risks, such as investing only in safe environments, increasing the required return, adapting to particular business environment conditions, sharing risks with other firms [8], improving relative bargaining power [9], transferring risks to an insurance company [16], reducing vulnerabilities [17], spreading risk by investing in several countries, enhancing the core competitiveness [18], and implementing localization and involvement strategies [1, 19].

Previous studies regarding risk management in construction projects have covered a wide variety of areas, such as overall risk management [20], safety risk management [21], financial risk management [22], quality risk management [23], risk assessment [24], advanced technology-driven risk management [25], and risk management in publicprivate partnerships [26, 27]. However, less attention has been devoted to political risk management in international construction projects. In some studies, political risk was mentioned only as a subset of external risks [28, 29].

Several studies have been conducted to identify political risk events $[2,30]$ and political risk factors $[5,6,31]$ in international construction projects. Although these studies can help international contractors gain a better understanding of political risks in international construction projects, they provide less guidance regarding how to manage political risk. It is obvious that knowledge and experiences associated with political risk management should be extended to the international construction business by considering overall political risk management strategies throughout the life of projects and the interrelation between the project and firm levels.

\section{Methods}

3.1. Strategy Identification and Survey. Based on an overview of the literature on political risk and risk management, a total of 27 possible risk management strategies were identified and were coded as S01 to S27 (Table 1).

A pilot survey was performed with 10 experts to verify the comprehensiveness of the preliminary strategies. These experts included (1) four professors (one each from Australia, Hong Kong, Singapore, and South Africa) engaged in research on business management and risk management, (2) two professors (one each from the United States and China) engaged in research on project management, and (3) four senior managers (one each from China Communications Construction Group Limited, Power Construction Corporation of China, China State Construction Engineering Corporation, and China Railway Group Limited). All the 10 experts had more than 20 years of work experience in their field. In their suggestion, no strategies were added or deleted; instead, descriptions of some strategies were added to ensure accuracy in understanding and to avoid ambiguity. For example, "S01, making a higher tender offer" refers to the premium for the retained political risks of an ICE.

The pilot survey was used to develop a structured questionnaire that comprised three sections: (1) a brief introduction of political risk and a description of some strategies; (2) questions to profile the company, work experience, title, and location of the respondents; and (3) questions to evaluate the 
TABLE 1: Political risk management strategies.

\begin{tabular}{|c|c|c|c|c|c|c|c|c|c|}
\hline \multirow{2}{*}{ Strategy } & \multicolumn{9}{|c|}{ Reference } \\
\hline & {$[8]$} & {$[3]$} & {$[32]$} & {$[5]$} & {$[52]$} & {$[33]$} & {$[2]$} & {$[8]$} & [34] \\
\hline S01: making a higher tender offer & $\mathrm{X}$ & - & - & - & - & - & - & $\mathrm{X}$ & - \\
\hline S02: conducting market research & $\mathrm{X}$ & $\mathrm{X}$ & - & $\mathrm{X}$ & $\mathrm{X}$ & - & $\mathrm{X}$ & $\mathrm{X}$ & - \\
\hline S03: buying risk insurance & $\mathrm{X}$ & - & - & $\mathrm{X}$ & $\mathrm{X}$ & - & $\mathrm{X}$ & - & $\mathrm{X}$ \\
\hline S04: adopting optimal contracts & - & - & $\mathrm{X}$ & - & - & $\mathrm{X}$ & - & - & $\mathrm{X}$ \\
\hline S05: implementing a localization strategy & $\mathrm{X}$ & $\mathrm{X}$ & - & $\mathrm{X}$ & - & - & $\mathrm{X}$ & - & $\mathrm{X}$ \\
\hline S06: avoiding misconduct & $\mathrm{X}$ & $\mathrm{X}$ & - & $\mathrm{X}$ & - & - & $\mathrm{X}$ & - & $\mathrm{X}$ \\
\hline $\begin{array}{l}\text { S07: adopting closed management of the construction } \\
\text { site }\end{array}$ & $\mathrm{X}$ & - & - & $\mathrm{X}$ & $\mathrm{X}$ & - & $\mathrm{X}$ & $\mathrm{X}$ & - \\
\hline S08: supporting environmental protection & $\mathrm{X}$ & - & - & - & - & - & - & - & - \\
\hline S09: abiding by the traditional local culture & $\mathrm{X}$ & $\mathrm{X}$ & - & $\mathrm{X}$ & - & - & - & - & - \\
\hline S10: making contingency plans & $\mathrm{X}$ & - & - & - & $\mathrm{X}$ & - & $\mathrm{X}$ & $\mathrm{X}$ & $\mathrm{X}$ \\
\hline S11: obtaining the corresponding guarantee & - & - & - & $\mathrm{X}$ & - & $\mathrm{X}$ & $\mathrm{X}$ & - & $\mathrm{X}$ \\
\hline S12: implementing an emergency plan & $\mathrm{X}$ & - & - & - & $\mathrm{X}$ & - & $\mathrm{X}$ & $\mathrm{X}$ & $\mathrm{X}$ \\
\hline S13: forming joint ventures with local contractors & $\mathrm{X}$ & - & $\mathrm{X}$ & $\mathrm{X}$ & - & - & - & - & $\mathrm{X}$ \\
\hline S14: conducting a postresponse assessment & $\mathrm{X}$ & - & - & - & $\mathrm{X}$ & - & $\mathrm{X}$ & - & - \\
\hline S15: sending staff to training programs & $\mathrm{X}$ & - & - & - & - & - & - & - & $\mathrm{X}$ \\
\hline S16: settling disputes through renegotiation & - & - & $\mathrm{X}$ & $\mathrm{X}$ & - & - & - & - & $\mathrm{X}$ \\
\hline S17: choosing suitable projects & - & - & - & $\mathrm{X}$ & - & $\mathrm{X}$ & - & - & $\mathrm{X}$ \\
\hline S18: building proper relations with host governments & - & $\mathrm{X}$ & $\mathrm{X}$ & $\mathrm{X}$ & - & - & $\mathrm{X}$ & - & - \\
\hline $\begin{array}{l}\text { S19: maintaining good relations with powerful } \\
\text { groups }\end{array}$ & - & $\mathrm{X}$ & $\mathrm{X}$ & $\mathrm{X}$ & - & $\mathrm{X}$ & $\mathrm{X}$ & - & $X$ \\
\hline S20: creating links with local business & $\mathrm{X}$ & $\mathrm{X}$ & $\mathrm{X}$ & $\mathrm{X}$ & - & $\mathrm{X}$ & $\mathrm{X}$ & - & $\mathrm{X}$ \\
\hline S21: changing the operation strategies & - & - & $\mathrm{X}$ & - & - & $\mathrm{X}$ & $\mathrm{X}$ & $\mathrm{X}$ & - \\
\hline S22: controlling core and critical technology & - & $\mathrm{X}$ & - & - & - & $\mathrm{X}$ & - & $\mathrm{X}$ & $\mathrm{X}$ \\
\hline S23: choosing a suitable entry mode & $\mathrm{X}$ & - & - & $\mathrm{X}$ & - & $\mathrm{X}$ & $\mathrm{X}$ & $\mathrm{X}$ & $\mathrm{X}$ \\
\hline S24: employing capable local partners & $\mathrm{X}$ & $\mathrm{X}$ & $\mathrm{X}$ & $\mathrm{X}$ & - & $\mathrm{X}$ & - & - & $\mathrm{X}$ \\
\hline S25: building up reputation & $\mathrm{X}$ & - & - & $\mathrm{X}$ & - & - & $\mathrm{X}$ & - & - \\
\hline S26: allocating extra funds & - & - & $\mathrm{X}$ & - & $\mathrm{X}$ & - & $\mathrm{X}$ & - & - \\
\hline S27: maintaining good relations with the public & - & $\mathrm{X}$ & $\mathrm{X}$ & - & - & $\mathrm{X}$ & $\mathrm{X}$ & - & $\mathrm{X}$ \\
\hline
\end{tabular}

importance of the 27 strategies using a five-point Likert scale where $5=$ very high, $4=$ high, $3=$ medium, $2=$ low, and $1=$ very low.

Then, a list of selected experts was developed, and they included (1) 300 international academics who focus on related studies-their personal information was collected from their publications-and (2) 500 practitioners with extensive experience in international project management-drawn from 50 Chinese construction enterprises that were selected from the 2016 top 250 international contractors according to Engineering News-Record (ENR). The contact information of the 500 practitioners was collected from the Chinese construction management research sector, alumni associations, and the websites of their enterprises.

From March to May 2017, the questionnaire was disseminated to these experts and a total of 158 responses were returned, of which three were incomplete or inappropriately filled out. The valid 155 responses represent a response rate of 19\%. As indicated in Table 2, among the 155 respondents, 56 were from academia and 99 were from industry. All the respondents had over 5 years' work experience, and $52 \%$ had over 10 years' work experience in industry or academia. Of the 56 academics, 28 were from China (including Hong Kong and Macao), and another 28 were from overseas. Among the 99 practitioners, $38,26,9,5,8$, and 5 were from the divisions of Chinese construction enterprises in Asia (not including China), Africa, Europe, North America, South America, and
Australia, respectively. Moreover, all practitioners had experienced political risk in the overseas construction market.

3.2. Exploratory Factor Analysis. The exploratory factor analysis has proven to be very useful for identifying the potential relationships between several sets of data and has frequently been employed in studies related to construction management $[11,31,35]$. The exploratory factor analysis is often used to create theories in a new research area, such as components, correlations, and relative weightings of a list of variables [36].

A sample with 5-point Likert scale data used in exploratory factor analysis should meet two conditions: (1) the size of the valid sample must be greater than 100 or five times the number of items [37] and (2) the data for the sample must satisfy the recommended alpha reliability test, Bartlett's test of sphericity, and the Kaiser-Meyer-Olkin (KMO) test of sampling adequacy [31].

In this study, the number of valid questionnaires is 155 , Cronbach's alpha coefficient is $0.932(>0.700, \mathrm{~F}$ statistic $=17.382$, significance level $=0.000)$, the KMO index is $0.878(\geq 0.500)$, and Bartlett's test of sphericity $\left(\chi^{2}=1497.243, d f=205\right.$, significance level $=0.000)$ is significant $(p<0.050)$, indicating that these data are suitable for the exploratory factor analysis [38-40]. The factor analysis of the 27 political risk management strategies was performed using the principal component analysis and varimax 
TABLe 2: Profile of the respondents.

\begin{tabular}{|c|c|c|c|c|c|c|c|}
\hline \multirow[t]{2}{*}{ Characteristic } & \multirow[t]{2}{*}{ Categorization } & \multicolumn{2}{|c|}{$\begin{array}{c}\text { Academia } \\
(N=56)\end{array}$} & \multicolumn{2}{|c|}{$\begin{array}{c}\text { Practitioner } \\
(N=99)\end{array}$} & \multicolumn{2}{|c|}{$\begin{array}{c}\text { Overall } \\
(N=155)\end{array}$} \\
\hline & & $N$ & $\%$ & $N$ & $\%$ & $N$ & $\%$ \\
\hline \multirow{4}{*}{ Work experience } & Over 20 years & 8 & 14 & 10 & 10 & 18 & 12 \\
\hline & $16-20$ years & 15 & 27 & 12 & 12 & 27 & 17 \\
\hline & $11-15$ years & 17 & 30 & 28 & 28 & 45 & 29 \\
\hline & $5-10$ years & 16 & 29 & 49 & 49 & 65 & 42 \\
\hline \multirow{6}{*}{ Title } & Professor & 22 & 39 & - & - & 22 & 14 \\
\hline & Associate professor & 19 & 34 & - & - & 19 & 12 \\
\hline & Assistant professor/lecturer & 15 & 27 & - & - & 15 & 10 \\
\hline & Senior manager & - & - & 29 & 29 & 29 & 19 \\
\hline & Department manager & - & - & 28 & 28 & 28 & 18 \\
\hline & Project manager & - & - & 42 & 42 & 42 & 27 \\
\hline \multirow{7}{*}{ Location } & China & 28 & 50 & 8 & 8 & 36 & 23 \\
\hline & Asia (excl. China) & 14 & 25 & 38 & 38 & 52 & 34 \\
\hline & Africa & 2 & 4 & 26 & 26 & 28 & 18 \\
\hline & Europe & 5 & 9 & 9 & 9 & 14 & 9 \\
\hline & North America & 4 & 7 & 5 & 5 & 9 & 6 \\
\hline & South America & 0 & 0 & 8 & 8 & 8 & 5 \\
\hline & Australia & 3 & 5 & 5 & 5 & 8 & 5 \\
\hline
\end{tabular}

rotation methods implemented using SPSS 22.0 software. The number of components was determined by successively using latent root criteria (eigenvalues $>1.000$ ) [41]. As suggested by Malhotra, the cumulative variance of the produced components should be greater than $60.000 \%$. To increase the correlation between strategies and components, the qualified strategies in each component should have a factor loading $\geq 0.500$ [42]. The internal consistency of the components should satisfy two conditions: Cronbach's alpha of each component $\geq 0.700$ [38] and the item-to-total correlation of each retained measure $\geq 0.400$ [43].

\section{Results}

4.1. Results of the Questionnaire Survey. Table 3 presents the evaluation results of the 27 political management strategies. The average values of the 27 strategies range from 3.27 (S21, changing the strategies) to 4.40 (S17, choosing suitable projects). All of them were significantly greater than 3 at the $p=0.05$ level (two tailed) in the one-sample $t$-test, indicating that the 27 strategies had significant importance in managing political risk in international construction projects. The five most important strategies were (1) choosing suitable projects (S17, average value 4.40), (2) building proper relations with host governments ( $\mathrm{S} 18$, average value 4.30), (3) conducting market research ( $\mathrm{S} 02$, average value 4.29 ), (4) avoiding misconduct (S06, average value 4.26), and (5) choosing a suitable entry mode (S23, average value 4.22). The $p$ values of the 27 strategies were greater than 0.05 in the independent-sample $t$-test. Therefore, there were no significant differences in the average values of the strategies between scholars and practitioners.

4.2. Results of Exploratory Factor Analysis. As illustrated in Table 4, a total of six components with eigenvalues greater than 1.000 were explored. The cumulative variance of the six components was $61.208 \%$, thus exceeding $60.000 \%$. The 27 strategies were divided into the six components according to their loading on each component of more than 0.500 . Although the loading of strategy "S13 forming joint venture with local contractors" in the first component was 0.521 , it was still removed from subsequent analyses due to the low value of its communality $(0.399<0.500)$ and item-to-total correlations $(0.301<0.400)$. After the adjustment, Cronbach's alpha coefficient of the first component and the communalities of the remaining six strategies in the first component increased. Cronbach's alpha coefficients of the six components ranged from 0.743 to 0.857 , and the item-tototal correlations of the remaining 26 strategies ranged from 0.478 to 0.653 ; thus, the model is reliable.

4.3. Results of the Validity Test. The Pearson correlation analysis (2 tailed) was applied to check the validity of the results of the exploratory factor analysis. The strategies clustered into a component should be significantly correlated [44]. The results revealed that for each component all the strategies were correlated with the others, and thus, the strategies can explain political risk management in that dimension. Due to space limitations, only the correlations between strategies in the first component are presented in Table 5.

\section{Discussion}

5.1. Connotation of the Components. The connotation of each component is determined by the commonalities of the remaining measures it contains. On the basis of project management, risk management, and strategic management theories, the 6 components were renamed as follows: (1) making correct decisions (C1), (2) reducing unnecessary mistakes (C2), (3) completing full preparations (C3), (4) shaping a good environment (C4), (5) conducting favorable 
TABLE 3: Ranking of the political risk management strategies.

\begin{tabular}{|c|c|c|c|c|c|c|c|c|}
\hline \multirow{2}{*}{ Strategy } & \multicolumn{2}{|c|}{ Academia } & \multicolumn{2}{|c|}{ Industry } & \multirow{2}{*}{$p$ value } & \multicolumn{3}{|c|}{ Overall } \\
\hline & Mean & Rank & Mean & Rank & & Mean & Rank & $p$ value \\
\hline S01: making a higher tender offer & 3.99 & 11 & 4.00 & 11 & 0.906 & 4.00 & 11 & $<0.001^{\mathrm{a}}$ \\
\hline S02: conducting market research & 4.45 & 3 & 4.20 & 5 & 0.282 & 4.29 & 3 & $<0.001^{\mathrm{a}}$ \\
\hline S03: buying risk insurance & 4.03 & 10 & 4.06 & 9 & 0.697 & 4.05 & 10 & $<0.001^{\mathrm{a}}$ \\
\hline S04: adopting optimal contracts & 4.12 & 6 & 4.23 & 3 & 0.261 & 4.19 & 6 & $<0.001^{\mathrm{a}}$ \\
\hline S05: implementing a localization strategy & 4.42 & 4 & 4.06 & 10 & 0.197 & 4.19 & 7 & $<0.001^{\mathrm{a}}$ \\
\hline S06: avoiding misconduct & 4.45 & 2 & 4.15 & 6 & 0.089 & 4.26 & 4 & $<0.001^{\mathrm{a}}$ \\
\hline $\begin{array}{l}\text { S07: adopting closed management of the construction } \\
\text { site }\end{array}$ & 3.41 & 22 & 3.85 & 12 & 0.537 & 3.69 & 18 & $<0.001^{\mathrm{a}}$ \\
\hline S08: supporting environmental protection & 3.75 & 14 & 3.82 & 15 & 0.831 & 3.80 & 14 & $<0.001^{\mathrm{a}}$ \\
\hline S09: abiding by the traditional local culture & 3.90 & 13 & 3.81 & 16 & 0.863 & 3.84 & 13 & $<0.001^{\mathrm{a}}$ \\
\hline S10: making contingency plans & 4.10 & 9 & 4.09 & 8 & 0.606 & 4.09 & 9 & $<0.001^{\mathrm{a}}$ \\
\hline S11: obtaining the corresponding guarantee & 3.98 & 12 & 4.22 & 4 & 0.401 & 4.14 & 8 & $<0.001^{\mathrm{a}}$ \\
\hline S12: implementing an emergency plan & 3.18 & 26 & 3.55 & 23 & 0.244 & 3.42 & 24 & $<0.001^{\mathrm{a}}$ \\
\hline S13: forming joint ventures with local contractors & 3.58 & 16 & 3.77 & 18 & 0.182 & 3.70 & 17 & $<0.001^{\mathrm{a}}$ \\
\hline S14: conducting a postresponse assessment & 3.16 & 27 & 3.41 & 26 & 0.537 & 3.32 & 26 & $<0.001^{\mathrm{a}}$ \\
\hline S15: sending staff to training programs & 3.43 & 20 & 3.62 & 21 & 0.628 & 3.55 & 21 & $<0.001^{\mathrm{a}}$ \\
\hline S16: settling disputes through renegotiation & 3.28 & 25 & 3.43 & 25 & 0.617 & 3.38 & 25 & $<0.001^{\mathrm{a}}$ \\
\hline S17: choosing suitable projects & 4.54 & 1 & 4.32 & 2 & 0.439 & 4.40 & 1 & $<0.001^{\mathrm{a}}$ \\
\hline S18: building proper relations with host governments & 4.12 & 7 & 4.42 & 1 & 0.223 & 4.31 & 2 & $<0.001^{\mathrm{a}}$ \\
\hline $\begin{array}{l}\text { S19: maintaining good relations with powerful } \\
\text { groups }\end{array}$ & 3.52 & 17 & 3.85 & 13 & 0.537 & 3.73 & 15 & $<0.001^{\mathrm{a}}$ \\
\hline S20: creating links with local business & 3.43 & 21 & 3.70 & 19 & 0.377 & 3.60 & 20 & $<0.001^{\mathrm{a}}$ \\
\hline S21: changing the operation strategies & 3.36 & 24 & 3.22 & 27 & 0.236 & 3.27 & 27 & $<0.001^{\mathrm{a}}$ \\
\hline S22: controlling core and critical technology & 4.10 & 8 & 3.80 & 17 & 0.301 & 3.91 & 12 & $<0.001^{\mathrm{a}}$ \\
\hline S23: choosing a suitable entry mode & 4.37 & 5 & 4.14 & 7 & 0.439 & 4.22 & 5 & $<0.001^{\mathrm{a}}$ \\
\hline S24: employing capable local partners & 3.66 & 15 & 3.66 & 20 & 0.725 & 3.66 & 19 & $<0.001^{\mathrm{a}}$ \\
\hline S25: building up reputation & 3.47 & 19 & 3.47 & 24 & 0.912 & 3.47 & 23 & $<0.001^{\mathrm{a}}$ \\
\hline S26: allocating extra funds & 3.39 & 23 & 3.59 & 22 & 0.275 & 3.52 & 22 & $<0.001^{\mathrm{a}}$ \\
\hline S27: maintaining good relations with the public & 3.49 & 18 & 3.83 & 14 & 0.137 & 3.71 & 16 & $<0.001^{\mathrm{a}}$ \\
\hline
\end{tabular}

Note. ${ }^{a}$ One-sample $t$-test result is significant (test value $=3$ ) at the $p=0.05$ significance level (two tailed)

negotiations (C5), and (6) obtaining a reasonable response (C6).

As shown in Figure 1, the six components may be divided into two dimensions of political risk management. Making correct decisions (C1), reducing unnecessary mistakes (C2), and obtaining a reasonable response (C6) are the components related to the reduction of risk exposure. When an ICE has a lower risk exposure, it has a lower risk level. In contrast, completing full preparations (C3), shaping a good environment (C4), and conducting favorable negotiations (C5) are the components associated with the promotion of risk response capability. A higher risk response capability indicates that an ICE has higher viability in an uncertain environment and is less likely to suffer damage arising from political risk. The components in the exposure reduction and capability promotion dimensions accounted for $38.975 \%$ and $29.233 \%$ of the total variance, respectively, thus indicating the leading role of reducing risk exposure and the supplementary role of improving risk response capability in political risk management in international projects.

In addition, the six components may be divided into groups with proactive, moderate, and passive characteristics. First, the components with a proactive characteristic (C1 and C4, which accounted for $26.040 \%$ of the total variance) are those utilized when making decisions or adapting to the local environment. Second, the components with a moderate characteristic (C2 and C3, which accounted for $24.742 \%$ of the total variance) are those applicable to a specific market or environment without specific risks. Third, the components with a passive characteristic (C6 and C5, which accounted for $19.420 \%$ of the total variance) are those related to specific risks. Compared to the passive strategies, the proactive and moderate strategies occupy more important positions in political risk management. In addition, ICEs are more likely to be resilient to political risks in the global market if they perform well with regard to the proactive strategies.

5.2. Application of the Components. As shown in Figure 2, the six components can be regarded as typical management techniques that contribute to political risk management in three different phases: the preproject phase, project implementation phase, and postevent phases. In the preproject phase, the premanagement techniques $(\mathrm{C} 1, \mathrm{C} 5$, and $\mathrm{C} 3$, which accounted for $39.975 \%$ of the total variance) can provide guidance for ICEs to avoid or transfer unacceptable risks and imply a higher offer for retained risks. In the project implementation phase, the interim management techniques (C4 and C2, which accounted for $24.404 \%$ of the total variance) can help ICEs adapt to the particular environmental conditions of the host country and reduce the probability and potential impacts of risks. In the postevent 
TABLE 4: Results of the exploratory factor analysis.

\begin{tabular}{|c|c|c|c|c|c|c|c|c|}
\hline \multirow{2}{*}{ Strategy } & \multirow{2}{*}{ Communality } & \multirow{2}{*}{ Item-to-total correlation } & \multicolumn{6}{|c|}{ Component } \\
\hline & & & 1 & 2 & 3 & 4 & 5 & 6 \\
\hline S23 & 0.640 & 0.590 & 0.676 & - & - & - & - & - \\
\hline S05 & 0.530 & 0.490 & 0.653 & - & - & - & - & - \\
\hline S17 & 0.575 & 0.572 & 0.617 & - & - & - & - & - \\
\hline S22 & 0.632 & 0.585 & 0.598 & - & - & - & - & - \\
\hline S18 & 0.565 & 0.482 & 0.541 & - & - & - & - & - \\
\hline S02 & 0.652 & 0.511 & 0.509 & - & - & - & - & - \\
\hline S06 & 0.730 & 0.579 & - & 0.683 & - & - & - & - \\
\hline S07 & 0.648 & 0.497 & - & 0.667 & - & - & - & - \\
\hline S24 & 0.667 & 0.612 & - & 0.617 & - & - & - & - \\
\hline S08 & 0.543 & 0.515 & - & 0.595 & - & - & - & - \\
\hline S09 & 0.621 & 0.611 & - & 0.509 & - & - & - & - \\
\hline S15 & 0.742 & 0.592 & - & - & 0.739 & - & - & - \\
\hline S26 & 0.679 & 0.516 & - & - & 0.670 & - & - & - \\
\hline S03 & 0.512 & 0.527 & - & - & 0.525 & - & - & - \\
\hline S10 & 0.479 & 0.542 & - & - & 0.507 & - & - & - \\
\hline S27 & 0.532 & 0.621 & - & - & - & 0.682 & - & - \\
\hline S25 & 0.697 & 0.629 & - & - & - & 0.672 & - & - \\
\hline S20 & 0.632 & 0.637 & - & - & - & 0.586 & - & - \\
\hline S19 & 0.581 & 0.589 & - & - & - & 0.547 & - & - \\
\hline S04 & 0.561 & 0.478 & - & - & - & - & 0.663 & - \\
\hline S01 & 0.548 & 0.551 & - & - & - & - & 0.567 & - \\
\hline S11 & 0.629 & 0.557 & - & - & - & - & 0.550 & - \\
\hline S16 & 0.611 & 0.538 & - & - & - & - & - & 0.631 \\
\hline S12 & 0.710 & 0.539 & - & - & - & - & - & 0.618 \\
\hline S21 & 0.579 & 0.571 & - & - & - & - & - & 0.522 \\
\hline S14 & 0.576 & 0.653 & - & - & - & - & - & 0.502 \\
\hline \multicolumn{3}{|c|}{ Cronbach's alpha } & 0.857 & 0.832 & 0.811 & 0.767 & 0.743 & 0.758 \\
\hline \multicolumn{3}{|c|}{ Eigenvalues } & 6.483 & 2.867 & 2.310 & 1.451 & 1.162 & 1.100 \\
\hline \multicolumn{3}{|c|}{ Variance $(\%)$} & 15.233 & 13.587 & 11.155 & 10.817 & 9.265 & 8.150 \\
\hline \multicolumn{3}{|c|}{ Cumulative variance (\%) } & 15.233 & 28.820 & 39.975 & 50.793 & 60.058 & 68.208 \\
\hline
\end{tabular}

Note. Only loadings of 0.500 or above are shown. Extraction method: principal component analysis. Rotation method: varimax with Kaiser normalization. Rotation converged in 10 iterations.

phase, the postmanagement techniques (C6, 10.155\% of the total variance) can help ICEs relieve the actual impacts of political risk and accumulate experience in political risk management.

5.2.1. Making Correct Decisions (C1). This component explained the largest percentage of the total variance (15.233\%) and contains six strategies: (1) conducting market research (S02), (2) choosing a suitable entry mode (S23), (3) choosing suitable projects (S17), (4) building proper relations with host governments (S18), (5) implementing a localization strategy (S05), and (6) controlling core and critical technology (S22). The average values of these six strategies $(4.29,4.21,4.40,4.31,4.19$, and 3.91, resp.) were relatively high, ranking $3 \mathrm{rd}, 5$ th, 1 st, $2 \mathrm{nd}$, 7 th, and 12 th, respectively, among the 27 strategies. All of them are strongly associated with decision-making activities, which can be observed as the most important part of political risk management.

Market research is a basic task for ICEs before they enter a country or contract a new project $[3,8]$. Information about the target market can be obtained from the websites or reports of international organizations (e.g., The World Bank,
TABLE 5: Pearson correlations for component one.

\begin{tabular}{lcccccc}
\hline & S23 & S05 & S17 & S22 & S18 & S02 \\
\hline S23 & 1.000 & $0.602^{\mathrm{b}}$ & $0.477^{\mathrm{b}}$ & $0.467^{\mathrm{b}}$ & $0.564^{\mathrm{b}}$ & $0.581^{\mathrm{b}}$ \\
S05 & - & 1.000 & $0.388^{\mathrm{a}}$ & $0.491^{\mathrm{b}}$ & $0.413^{\mathrm{b}}$ & $0.432^{\mathrm{b}}$ \\
S17 & - & - & 1.000 & $0.306^{\mathrm{b}}$ & $0.625^{\mathrm{b}}$ & $0.589^{\mathrm{b}}$ \\
S22 & - & - & - & 1.000 & $0.427^{\mathrm{a}}$ & $0.371^{\mathrm{b}}$ \\
S18 & - & - & - & - & 1.000 & $0.689^{\mathrm{b}}$ \\
S02 & - & - & - & - & - & 1.000 \\
\hline
\end{tabular}

${ }^{\mathrm{a}}$ Correlation is significant at the $p=0.05$ level ( 2 tailed). ${ }^{\mathrm{b}}$ Correlation is significant at the $p=0.01$ level ( 2 tailed).

International Monetary Fund, and World Trade Organization), nongovernmental organizations (e.g., industry associations, commercial banks, and insurance companies), and government agencies (e.g., ministries of construction, ministries of commerce, and foreign ministries) in the host and home countries. Based on a clear understanding of market conditions, ICEs can identify potential political events and their probabilities by using risk assessment. The results of market research and risk assessment can be used as evidence for decision making $[45,46]$. In a high-risk country, ICEs should choose a flexible entry mode (e.g., sole-venture projects and joint-venture projects with short durations) to reduce their exposure to environmental 


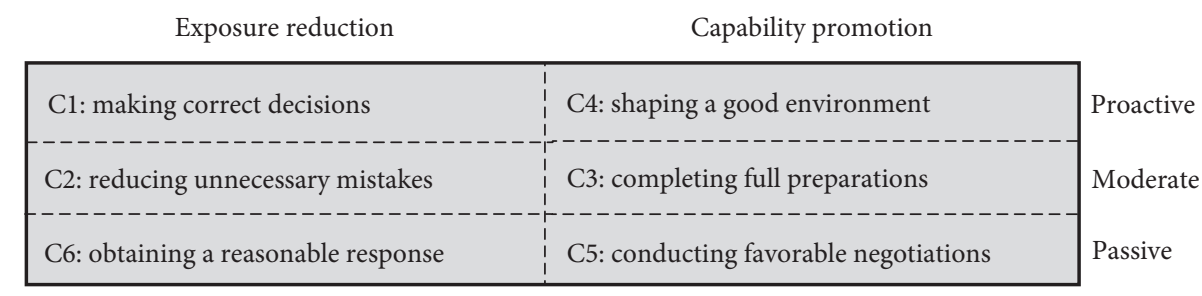

FIGURE 1: Characteristics of the components.


FIgURE 2: Application of the components.

fluctuations [6]. However, in a low-risk country, ICEs can choose a permanent entry mode (e.g., a sole-venture company, a joint-venture company, and branch offices) $[6,47]$ to seek further development and higher profits. In choosing projects, ICEs should select those that are suited to their capacities, fit their interests, and utilize their own expertise. In addition, if ICEs choose a project greatly desired by the host governments and the local population, a good operating environment will be established, and less political risk will exist [3]. The relationship between ICEs and host governments is a very important factor that has great potential influence on political risk management $[4,48]$. In a politically stable country, ICEs that have a good relationship with host governments can obtain more support and benefits, such as convenient approval procedures, less government intervention, smooth information and communication channels, and sufficient government guarantees. In contrast, in politically unstable countries, a lowinvolvement strategy with host governments is a better choice and can help ICEs avoid becoming involved in political struggles. Localization is a common strategy in international business and can help ICEs integrate into the host society [6]. ICEs with a high level of localization will be free from discrimination and opposition [7, 49]. ICEs are paying increasing attention to the control of core and critical technologies because the impact of technology on competition between ICEs is increasingly fierce. Moreover, ICEs with core and critical technologies will have an important position and a stronger voice in negotiations with host governments and experience less government interference in the project implementation phase $[6,50]$.

5.2.2. Conducting Favorable Negotiations (C5). Three strategies are assigned to this component and account for 9.265\% of the total variance: (1) adopting optimal contracts (S04), (2) making a higher tender offer (S01), and (3) obtaining the corresponding guarantee (S11). All of these strategies are strongly related to bidding and contract activities during the early stages of a project.

In the business negotiation stage, the first important issue for ICEs is to select internationally accepted standard contracts and exclude contractual clauses and conditions that are not practiced locally $[32,34]$. The contract clauses, such as payment terms, liability for a breach of the terms of the dispute resolution clause, intellectual property clauses, force majeure clauses, and confidentiality provisions should be drafted properly since they are the foundation for the execution of the transaction and the settlement of disputes. When a political risk event occurs, the risk premium can potentially compensate for an ICE's losses. Therefore, if ICEs must confront and retain some risks, an increase in the required return can be provided by making a higher tender offer to protect themselves against those risks [33]. Two common methods are used to increase the tender offer: appropriately increasing the price of materials and using adjustment coefficients. Of course, raising the tender offer cannot make up for all the potential losses, and if the price is too high, the probability of winning the bid will decrease [51]. International guarantee regulations are an efficacious remedy for defects in local remedies, international arbitration, and diplomatic protection [52]. ICEs should try their best to come to an agreement with the host government to obtain the proper guarantees to help them restrict improper behaviors by the host government $[46,33]$, obtain compensation in a timely manner, and avoid increased losses.

5.2.3. Completing Full Preparations (C3). This component explained $11.155 \%$ of the total variance and contained four strategies: (1) making contingency plans (S10), (2) sending staff to training programs (S15), (3) allocating extra funds (S26), and (4) purchasing risk insurance (S03), ranking 9th, 21 st, 22nd, and 10th, respectively, among the 27 strategies. The four strategies are related to the preparations for risk 
response and should be performed before the commencement of construction works.

It is sensible for ICEs to have a written contingency plan for potential political risk to protect their own interests and safety $[46,53]$. The content of a contingency plan should include (1) risk prediction and analysis, (2) a dispute settlement mechanism, (3) action roles and responsibilities, (4) equipment and tools, and (5) steps and strategies. The cases in Yemen and Libya demonstrate that a good evacuation plan can effectively protect the safety of international contractors, even during a war. Additionally, appropriate training programs (e.g., antigraft, safety, and self-protection programs) should be provided for employees in accordance with the company's code of conduct and safety policies and procedures. Political risk management should be supported by allocating extra funds [32], which can enhance the flexibility of ICEs in an uncertain environment. An increasing number of multinational enterprises are willing to buy political risk insurance, which is considered an important measure to manage political risks. Political risk insurance can reduce the uninsured losses caused by various types of political risk, such as war, internal conflict, transfer restrictions, repudiation of debt, and expropriation [16]. In some cases, political risk is also used as a bargaining chip for companies to secure long-term loans and settle disputes with governments [54]. Political risk insurance can be purchased from three types of providers: (1) public providers such as the African Trade Insurance Agency and the Asian Development Bank, (2) private providers such as the insurance centers in London and the United States, and (3) reinsurers such as Hannover Re (Germany) and the China Export and Credit Insurance Corporation.

5.2.4. Shaping a Good Environment (C4). This component was responsible for $10.817 \%$ of the total variance and included four strategies: (1) maintaining good relations with powerful groups (S19), (2) maintaining good relations with the public (S27), (3) linking with local businesses (S20), and (4) building a reputation (S25). These four strategies can help enterprises create a good operating environment in a foreign land.

ICEs should maintain good relations with powerful groups (e.g., the media, labor unions, business coalitions, industry associations, consumer associations, and environmental protection groups) in host countries [3]. Not only are powerful groups important influencers in policy making, but they also play significant roles in the economic and social environment [46]. Good relations with powerful local groups are very helpful for ICEs in terms of obtaining the necessary resources and reducing interference. For example, ICEs can obtain useful market and policy information through partnerships with industry associations and business coalitions [55], but they may suffer from extra checks from labor unions because of disputes with local workers [56]. It is well known that opposition to international construction projects is often initiated by the local public [32]. Therefore, maintaining good relations with the public is beneficial for ICEs in terms of avoiding unnecessary trouble.
Linking with local businesses, such as choosing wellconnected local business partners or strengthening cooperation with local enterprises, can help ICEs reduce their image as foreigners [46] and therefore reduce their probability of becoming involved in micropolitical processes $[8,49]$. Corporate reputation refers to the extent to which an enterprise garners public trust and praise and the extent to which an enterprise influences the public [57]. Corporate reputation represents the sum of a multinational enterprise's ability to obtain social recognition, resources, opportunities, and support and to achieve value creation in the host country. A good reputation can allow ICEs to respond quickly to a crisis and enhance their ability to resist risk. Building a corporate reputation is a long-term process, and hence, ICEs must make unremitting efforts (e.g., taking into account the interests of the local public, participating in local public welfare activities, and cultivating a good image via marketing efforts) to create a good reputation $[58,59]$.

5.2.5. Reducing Unnecessary Mistakes (C2). This component accounted for $13.587 \%$ of the total variance and consisted of five strategies: (1) avoiding misconduct (S06), (2) employing capable local partners (S24), (3) supporting environmental protection (S08), (4) abiding by the local culture (S09), and (5) adopting closed management of the construction site (S07). The strategies in this component are strongly related to the policy of reducing ICEs' unnecessary mistakes in their operations.

Many cases have shown that political risk is closely linked to misconduct (e.g., bribery, legal violations, wages in arrears, dishonest acts, environmental pollution, and cultural conflicts) by ICEs during the project implementation phase $[34,56]$. For example, in a very racist country, ICEs' discrimination against certain local people may lead to racial tension, thus causing government interference; in a corruption-ridden country, unhealthy relationships between enterprises and the host government may cause protests or opposition from the public. Thus, ICEs should act strictly according to a code of conduct to eliminate political risk caused by their own mistakes. Cultural conflicts often occur in international marketing practice. Respecting and abiding by the local culture will help ICEs to mitigate the risks arising from cultural conflicts $[3,8]$. Environmental protection and sustainable development are currently major trends. Many people as well as governments have increasingly begun to pay attention to environmental protection. Thus, taking part in the protection and construction of the ecological environment will help ICEs maintain good relations with the local population. The market skills and knowledge of experienced and qualified local partners (e.g., lawyers, subcontractors, suppliers, and agencies) are effective supplements for ICEs, especially for ICEs that lack practical market experience in the host country. Employing resourceful local partners can help ICEs not only reduce costs and improve work efficiency but also gain legitimacy under institutional pressure $[1,60]$. Closed management of construction sites with security systems (e.g., security guards, 
monitoring devices, and alarm mechanisms) is an effective means for ICEs to prevent crime, terrorist attacks, and external conflicts, thus keeping sites safe in an unstable environment [5].

5.2.6. Obtaining a Reasonable Response (C6). Strategies clustered in this component are generally associated with risk response when a risk occurs, accounting for $10.155 \%$ of the total variance. This strategy contains four strategies: (1) implementing an emergency plan (S12), (2) settling disputes through renegotiation (S16), (3) changing the operation strategies (S21), and (4) conducting a postresponse assessment (S14).

Once political risk events arise, ICEs should immediately implement a risk emergency plan to reduce damage and better protect their security [34]. For example, at the onset of wars, ICEs should promptly contact the embassy, suspend construction work, and evacuate their employees. Organizational capability and flexible adaptability are important weapons that ICEs can use to address difficulties in the emergency plan implementation process. In special cases, ICEs can also seek the support of the general public, local governments, their home countries, international organizations, and the media to cope with intractable threats. After the threat disappears, reassessing the residual risks is an effective means through which ICEs can adjust project plans in terms of resources, schedules, and costs and judge whether there is a need to make a claim, renegotiate, or change the operations strategies $[46,52]$. In the course of claims or renegotiations, any disputes should be settled through reasonable channels, such as demanding compensation based on the contract or guarantee treaty, making use of international conventions, or resorting to arbitration or conciliation [54]. It should be noted that successful claims and renegotiations by ICEs are based on adequate evidence of their losses. Therefore, they must protect related documents even in deteriorating situations [5]. Lessons learned from practical project cases are more valuable than those learned from books and can be consolidated through a postresponse assessment. These lessons and knowledge can help ICEs to improve their capacity for political risk management and therefore to effectively address similar political risks in the future.

\section{Conclusions}

Political risk is a major problem encountered by ICEs in international construction projects. It is thus necessary to identify the strategies that can help ICEs address political risk. On the basis of a comprehensive literature review, 27 possible political risk management strategies were identified. The results of the questionnaire survey indicated that all the strategies were important for political risk management in international construction projects. Five strategies, including (1) choosing suitable projects (S17), (2) building proper relations with host governments (S18), (3) conducting market research (S02), (4) avoiding misconduct
(S06), and (5) choosing a suitable entry mode (S23), were the most important strategies according to their average values.

Through the exploratory factor analysis, the 27 strategies were clustered into six components: (1) making correct decisions (C1), (2) reducing unnecessary mistakes (C2), (3) completing full preparations (C3), (4) shaping a good environment (C4), (5) conducting favorable negotiations (C5), and (6) obtaining a reasonable response (C6). The components ( $\mathrm{C} 1$, $\mathrm{C} 2$, and $\mathrm{C6}$ ) of the exposure decline dimension have higher contributions to political risk management than the components $(\mathrm{C} 4, \mathrm{C} 3$, and $\mathrm{C} 5)$ of the capacity promotion dimension. In addition, components with a proactive characteristic $(\mathrm{C} 1$ and $\mathrm{C} 4)$, components with a moderate characteristic (C2 and C3), and components with a passive characteristic (C5 and C6) can be ranked from the most to the least important for political risk management according to their cumulative variance.

Furthermore, the six components independently contribute to political risk management in three different phases. In the preproject phase, premanagement techniques (C1, C3, and C5) can help ICEs avoid or transfer unacceptable risks and improve quotes for the retained risk. In the project implementation phase, interim management techniques ( $\mathrm{C} 2$ and $\mathrm{C} 4$ ) are conducive to reducing risk and promoting ICEs' adaptation to the overseas construction market. In the postevent phase, postmanagement techniques (C6) are useful for ICEs to eliminate their actual risk and to accumulate experience with political risk management. The high cumulative variance of the premanagement strategies indicated that the main tasks of political risk management should be performed in the early stage of a project.

Compared to the respondents in the academic group, who were from different countries, all the respondents in the practitioner group were from Chinese construction enterprises, which is a limitation of this study. Nevertheless, the results of the independent-sample $t$-test revealed no significant differences in the responses between academics and practitioners. In addition, conditions in the global market are typically the same for ICEs from different countries. The relevant experience of the respondents is a reference for all practitioners, regardless of their nationalities. However, the characteristics of different enterprises and the actual conditions in different countries should be carefully considered when implementing these strategies. Further work could focus on evaluating these strategies with samples from different enterprises or different countries to increase the practical validity of the results. Despite its limitations, this study is a useful reference for academics and practitioners in terms of gaining an in-depth understanding of political risk management in international construction projects and provides guidance for ICEs to manage political risk when venturing outside their home countries.

\section{Data Availability}

The data from the 127 returned questionnaires used to support the findings of this study are available from the corresponding author upon request. 


\section{Conflicts of Interest}

The authors declare that they have no conflicts of interest.

\section{Acknowledgments}

This study was supported by the National Natural Science Foundation of China (NSFC-71372199 and 71771052) and the Postgraduate Research and Practice Innovation Program of Jiangsu Province, China (KYCX17-0191).

\section{References}

[1] S. P. Low and H. B. Jiang, "Internationalization of Chinese construction enterprises," Journal of Construction Engineering and Management, vol. 129, no. 6, pp. 589-598, 2004.

[2] X. Deng and S. P. Low, "Understanding the critical variables affecting the level of political risks in international construction projects," KSCE Journal of Civil Engineering, vol. 17, no. 5, pp. 895-907, 2013.

[3] D. B. Ashley and J. J. Bonner, "Political risks in international construction," Journal of Construction Engineering and Management, vol. 113, no. 3, pp. 447-467, 1987.

[4] F. Y. Y. Ling and V. T. P. Hoang, "Political, economic, and legal risks faced in international projects: case study of Vietnam," Journal of professional issues in engineering education and practice, vol. 136, no. 3, pp. 156-164, 2010.

[5] T. Chang, X. Deng, J. Zuo, and J. Yuan, "Political risks in Central Asian countries: factors and strategies," Journal of Management in Engineering, vol. 34, no. 2, article 04017059, 2018.

[6] X. Deng and S. P. Low, "Exploring critical variables that affect political risk level in international construction projects: case study from Chinese contractors," Journal of Professional Issues in Engineering Education and Practice, vol. 140, no. 1, article 04013002, 2014.

[7] R. Jia, Q. Li, X. Deng, X. Zhao, and J. Yuan, "Entry mode taxonomy and choice of Chinese international construction companies," Journal of Management in Engineering, vol. 33, no. 3, article 04016058, 2017.

[8] J. J. Bonner, Political Risk Analysis System for Multinational Contractors, Massachusetts Institute of Technology, Cambridge, MA, USA, 1981.

[9] C. H. Brink, Measuring Political Risk: Risks to Foreign Investment, Routledge, Abingdon, UK, 2017.

[10] S. P. Low, J. Y. Liu, S. H. M. Ng, and X. Liu, "Enterprise risk management and the performance of local contractors in Singapore," International Journal of Construction Management, vol. 13, no. 2, pp. 27-41, 2013.

[11] X. Zhao, B. G. Hwang, and S. P. Low, "Critical success factors for enterprise risk management in Chinese construction companies," Construction Management and Economics, vol. 31, no. 12, pp. 1199-1214, 2013.

[12] M. Leitch, "ISO 31000: 2009-the new international standard on risk management," Risk analysis, vol. 30, no. 6, pp. 887$892,2010$.

[13] A. P. Liebenberg and R. E. Hoyt, "The determinants of enterprise risk management: evidence from the appointment of chief risk officers," Risk Management and Insurance Review, vol. 6, no. 1, pp. 37-52, 2003.

[14] R. J. Chapman, Simple Tools and Techniques for Enterprise Risk Management, John Wiley and Sons, Hoboken, NJ, USA, 2006.

[15] L. A. Gordon, M. P. Loeb, and C. Y. Tseng, "Enterprise risk management and firm performance: a contingency perspective,"
Journal of Accounting and Public Policy, vol. 28, no. 4, pp. 301-27, 2009.

[16] J. Jakobsen, Political Risk and the Multinational Company, Tapir Academic Press, Trondheim, Norway, 2012.

[17] R. Grosse, "The bargaining relationship between foreign MNEs and host governments in Latin America," International Trade Journal, vol. 10, no. 4, pp. 467-500, 1996.

[18] J. G. Frynas and K. Mellahi, "Political risks as firm-specific (dis)advantages: evidence on transnational oil firms in Nigeria," Thunderbird International Business Review, vol. 45, no. 5, pp. 541-565, 2003.

[19] J. F. Hennart, "A transaction costs theory of equity joint ventures," Strategic Management Journal, vol. 9, no. 4, pp. 361-374, 1988.

[20] A. F. Serpella, X. Ferrada, R. Howard, and L. Rubio, "Risk management in construction projects: a knowledge-based approach," Procedia-Social and Behavioral Sciences, vol. 119, pp. 653-662, 2014.

[21] A. A. Karakhan and J. A. Gambatese, "Identification, quantification, and classification of potential safety risk for sustainable construction in the United States," Journal of Construction Engineering and Management, vol. 143, no. 7, article 04017018, 2017.

[22] A. Gilbert, B. K. Sovacool, P. Johnstone, and A. Stirling, "Cost overruns and financial risk in the construction of nuclear power reactors: a critical appraisal," Energy Policy, vol. 102, pp. 644-649, 2017.

[23] S. H. Mai and J. Wang, "Research on quality risk of EPC hydropower projects in Vietnam," World Journal of Engineering and Technology, vol. 5, no. 2, pp. 299-308, 2017.

[24] O. Taylan, A. O. Bafail, R. M. Abdulaal, and M. R. Kabli, "Construction projects selection and risk assessment by fuzzy AHP and fuzzy TOPSIS methodologies," Applied Soft Computing, vol. 17, pp. 105-116, 2014.

[25] X. Zhao, Y. Feng, J. Pienaar, and D. O’Brien, “Modelling paths of risks associated with BIM implementation in architectural, engineering and construction projects," Architectural Science Review, vol. 60, no. 6, pp. 472-482, 2017.

[26] B. G. Hwang, X. Zhao, and M. J. S. Gay, "Public private partnership projects in Singapore: factors, critical risks and preferred risk allocation from the perspective of contractors," International Journal of Project Management, vol. 31, no. 3, pp. 424-433, 2013.

[27] R. Burke and I. Demirag, "Risk transfer and stakeholder relationships in public private partnerships," Accounting Forum, vol. 41, no. 1, pp. 28-43, 2017.

[28] S. Q. Wang, R. L. Tiong, S. K. Ting, and D. Ashley, "Evaluation and management of foreign exchange and revenue risks in China's BOT projects," Construction Management and Economics, vol. 18, no. 2, pp. 197-207, 2000.

[29] J. Liu, X. Zhao, and P. Yan, "Risk paths in international construction projects: case study from Chinese contractors," Journal of Construction Engineering and Management, vol. 142, no. 6, article 05016002, 2016.

[30] A. A. Khattab, J. Anchor, and E. Davies, "Managerial perceptions of political risk in international projects," International Journal of Project Management, vol. 25, no. 7, pp. 734-743, 2007.

[31] X. Deng, S. P. Low, and X. Zhao, "Project system vulnerability to political risks in international construction projects: the case of Chinese contractors," Project Management Journal, vol. 45, no. 2, pp. 20-33, 2014.

[32] J. Liu, X. Zhao, and Y. Li, "Exploring the factors inducing contractors' unethical behavior: case of China," Journal of 
Professional Issues in Engineering Education and Practice, vol. 143, no. 3, article 04016023, 2016.

[33] J. Pallant, SPSS Survival Manual: A Step by Step Guide to Data Analysis Using SPSS, Open University Press, Buckingham, UK, 2010.

[34] R. L. Gorsuch, Factor Analysis, Erlbaum, Hillsdale, NJ, USA, 2nd edition, 1983.

[35] J. F. Hair, R. E. Anderson, R. L. Tatham, and W. C. Black, Multivariate Data Analysis, Prentice Hall, London, UK, 5th edition, 1998.

[36] H. F. Kaiser, “An index of factorial simplicity," Psychometrika, vol. 39, no. 1, pp. 31-36, 1974.

[37] M. S. Bartlett, "A note on the multiplying factors for various $\chi^{2}$ approximations," Journal of the Royal Statistical Society, vol. 16, no. 2, pp. 296-298, 1954.

[38] S. Sharma, Applied Multivariate Techniques, Wiley, New York, NY, USA, 1996.

[39] N. K. Malhotra, Marketing Research: An Apply Orientation, Prentice Hall, London, UK, 2nd edition, 1996.

[40] N. Kumar, L. K. Scheer, and J. B. E. M. Steenkamp, "The effects of supplier fairness on vulnerable resellers," Journal of marketing research, vol. 32, no. 1, pp. 54-65, 1995.

[41] X. Zhang, "Factor analysis of public clients' best-value objective in public-privately partnered infrastructure projects," Journal of Construction Engineering and Management, vol. 132, no. 9, pp. 956-965, 2006.

[42] J. Brustbauer, "Enterprise risk management in SMEs: towards a structural model," International Small Business Journal, vol. 34, no. 1, pp. 70-85, 2016.

[43] X. Deng, S. P. Low, Q. Li, and X. Zhao, "Developing competitive advantages in political risk management for international construction enterprises," Journal of Construction Engineering and Management, vol. 140, no. 9, article 04014040, 2014.

[44] I. Alon and M. A. Martin, "A normative model of macro political risk assessment," Multinational Business Review, vol. 6, no. 2, pp. 10-19, 1998.

[45] S. Q. Wang, R. L. K. Tiong, S. K. Ting, and D. Ashley, "Political risk: analysis of key contract clauses in China's BOT project," Journal of Construction Engineering and Management, vol. 125, no. 3, pp. 190-197, 1999.

[46] I. Alon and T. Herbert, "A stranger in a strange land: micro political risk and the multinational firm," Business Horizons, vol. 52, no. 2, pp. 127-137, 2009.

[47] J. Torre and D. H. Neckar, "Forecasting political risks for international operations," International Journal of Forecasting, vol. 4, no. 2, pp. 221-241, 1988.

[48] Y. Y. Ling and S. P. Low, "Legal risks faced by foreign architectural, engineering, and construction firms in China," Journal of Professional Issues in Engineering Education and Practice, vol. 133, no. 3, pp. 238-245, 2007.

[49] S. Q. Wang, M. F. Dulaimi, and M. Y. Aguria, "Risk management framework for construction projects in developing countries," Construction Management and Economics, vol. 22, no. 3, pp. 237-252, 2004.

[50] B. Akinci and M. Fischer, "Factors affecting contractors' risk of cost overburden," Journal of Management in Engineering, vol. 14, no. 1, pp. 67-76, 1998.

[51] W. Samuelson and L. Rosenthal, "Price movements as indicators of tender offer success," Journal of Finance, vol. 41, no. 2, pp. 481-499, 1986.

[52] R. J. Chapman, "The controlling influences on effective risk identification and assessment for construction design management," International Journal of Project Management, vol. 19, no. 3, pp. 147-160, 2001.

[53] N. Lee and J. E. Schaufelberger, "Risk management strategies for privatized infrastructure projects: study of the buildoperate-transfer approach in east Asia and the Pacific," Journal of Management in Engineering, vol. 30, no. 3, article 05014001, 2013.

[54] M. Anaam Hashmi, "Protection in a changing and volatile world: a study of political risk insurance providers," Managerial Finance, vol. 21, no. 4, pp. 52-64, 1995.

[55] J. C. Marques, "Industry business associations: self-interested or socially conscious?," Journal of Business Ethics, vol. 143, no. 4, pp. 733-751, 2017.

[56] H. Jauch, "Chinese investments in Africa: twenty-first century colonialism?"” New Labor Forum, vol. 20, no. 2, pp. 48-55, 2011.

[57] E. R. Gray and J. M. Balmer, "Managing corporate image and corporate reputation," Long Range Planning, vol. 31, no. 5, pp. 695-702, 1998.

[58] H. Wang, L. Tong, R. Takeuchi, and G. George, "Corporate social responsibility: an overview and new research directions thematic issue on corporate social responsibility," Academy of Management Journal, vol. 59, no. 2, pp. 534-544, 2016.

[59] E. Arikan, D. Kantur, C. Maden, and E. E. Telci, "Investigating the mediating role of corporate reputation on the relationship between corporate social responsibility and multiple stakeholder outcomes," Quality and Quantity, vol. 50, no. 1, pp. 129-149, 2016.

[60] C. M. Chan and S. Makino, "Legitimacy and multi-level institutional environments: implications for foreign subsidiary ownership structure," Journal of International Business Studies, vol. 38, no. 4, pp. 621-638, 2007. 




\section{Enfincering}
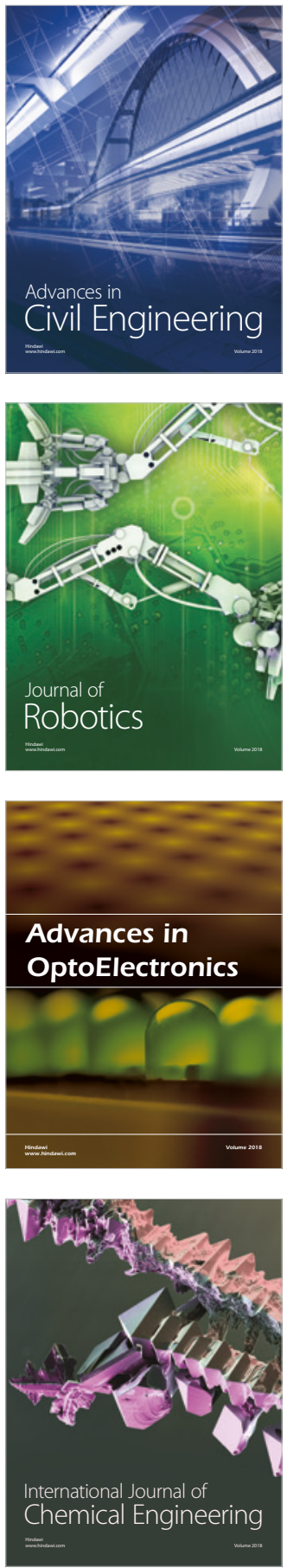

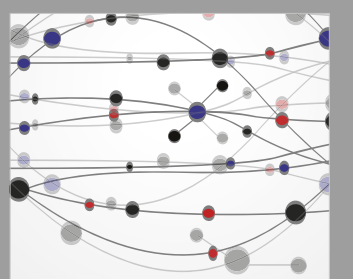

\section{Rotating \\ Machinery}

The Scientific World Journal

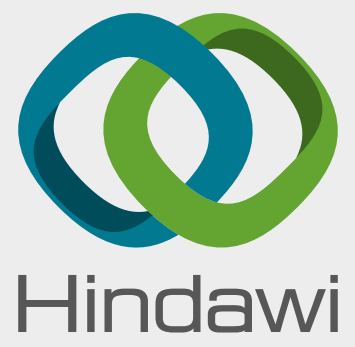

Submit your manuscripts at

www.hindawi.com
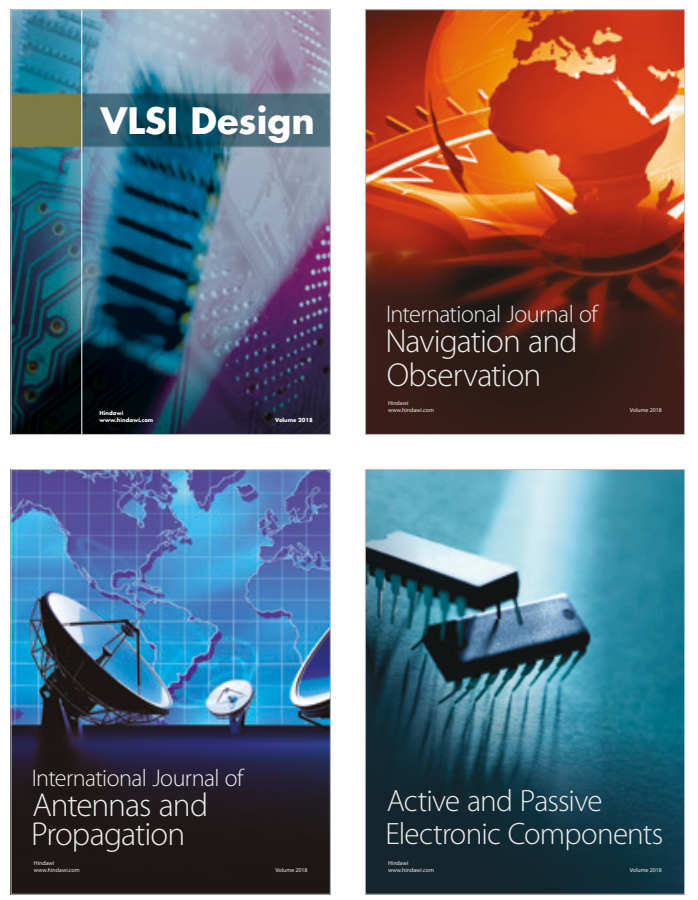
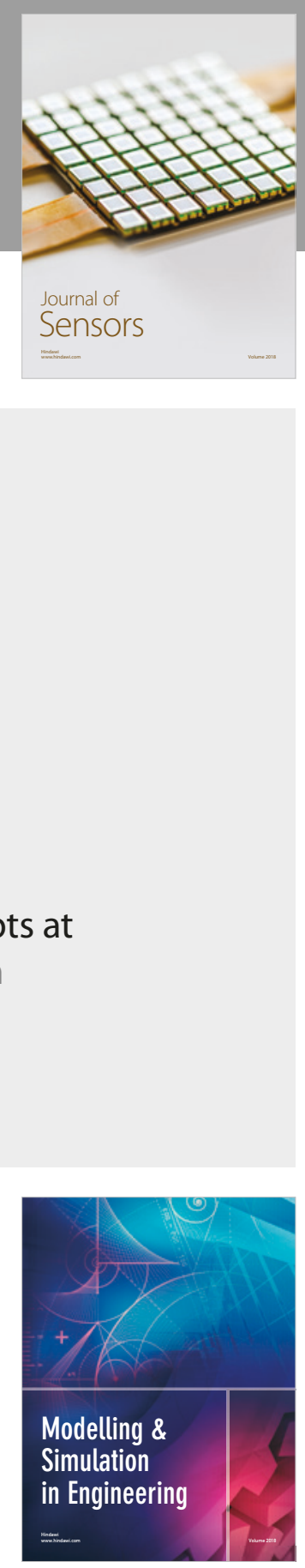

\section{Advances \\ Multimedia}
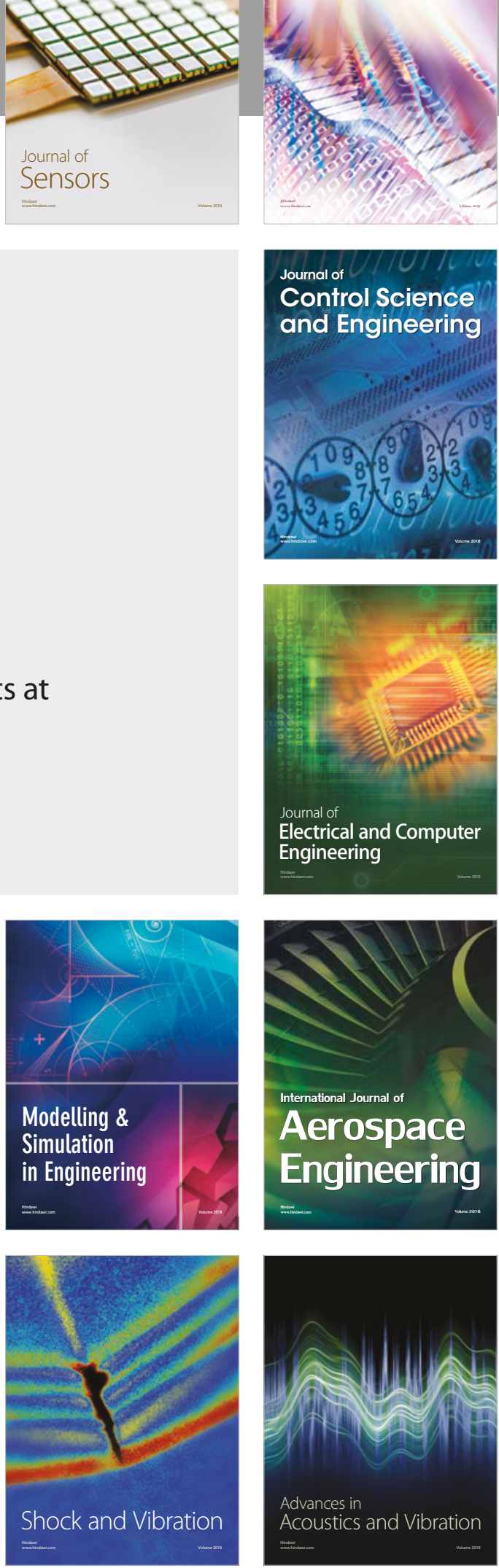